\title{
THE WOLF: REENACTING THE MYTH AND ARCHETYPE IN AMERICAN LITERATURE AND SOCIETY
}

\author{
Imelda Martín Junquera* \\ Universidad de León/GIECO-Franklin-UAH
}

\section{Abstract}

Taking as a point of departure The Crossing by Cormac McCarthy, the treatment of the wild figure of the "she" wolf and Clarisa Pinkola Estes's Women Who Run with the Wolves, it is my aim to apply an ecocritical and ecofeminist perspective to the study of the current status of the tradition that has focused on romanticizing or demonizing the figure of the wolf in American literature. It is also my intention to call attention to the current social responses of environmental activism with multiple demonstrations against the deliberate attempt of hunters and even local governments to exterminate the species because of the repeated attacks inflicted to cattle. In Estés' psychoanalytical study, the wolf works as a liberating figure, empowered with wildness, defying a tradition of patriarchal oppression for women, embedded in the common female unconscious as it is sanctioned in traditional literature.

Keywords: Myth, Wolf, Interspecies Communication, Extermination, Conservation.

\author{
EL LOBO: LA RECREACIÓN DEL MITO Y EL ARQUETIPO \\ EN LA LITERATURA Y LA SOCIEDAD AMERICANAS
}

\section{Resumen}

Mi intención en este estudio consiste en analizar el tratamiento de la figura salvaje de la loba en El cruce de Cormac McCarthy y Mujeres que corren con los lobos de Clarisa Pinkola Estés desde una perspectiva ecocrítica y ecofeminista. Pretendo en estas páginas aportar una visión actual del estado de una tradición literaria norteamericana que se ha centrado o bien en romantizar o demonizar la figura del lobo. Además, quiero llamar la atención sobre la cuestión del activismo medioambiental y la respuesta de la sociedad actual que se define, sobre todo, en acciones manifiestas contra el intento deliberado de grupos de cazadores y gobiernos locales de exterminar la especie, por culpa de sus ataques y el dańo que causan al ganado. En el estudio psicoanalítico de Estés, el lobo se presenta como una figura liberadora, empoderada con su salvajismo, y desafiando una tradición de opresión patriarcal sobre las mujeres implantada en el subconsciente femenino tal y como ha sido trasmitida en la literatura tradicional.

Palabras clave: mito, loba, diálogo entre especies, exterminio, conservación.

DOI: https://doi.org/10.25145/j.recaesin.2018.77.05

Revista Canaria de Estudios Ingleses, 77; november 2018, pp. 61-71; ISSN: e-2530-8335 
From the representation of the wolf as a danger to humanity to the embracement of the animal as the return to a wild status and the establishment of an effective communication between both species, the literature of the end of the $20^{\text {th }}$ century demonstrates a radical change in attitude, a vision of the wolf as an irreplaceable creature from an ecocentric perspective that proposes alternatives to the anthropocentric and ultimately androcentric one. Aldo Leopold, already in 1949, questioned this extermination of the wolf basing his statements on his theory of conservation and the certainty that this species was condemned to disappear:

In the northern parts of the lake states we have a few wolves left. Each state offers a bounty on wolves. In addition, it may invoke the expert services of the U.S. Fish and Wildlife Service in wolf-control. Yet both his agency and the several conservation commissions complain of an increasing number of localities where there are too many deer for the available feed. Foresters complain of periodic damage from too many rabbits. Why, then, continue the public policy of wolf extermination? We debate such questions in terms of economics and biology. The mammologists assert the wolf is the natural check on too many deer. The sportsmen reply they will take care of excess of deer. Another decade of argument and there will be no wolves to argue about. One conservation inkpot cancels another (195).

Hopefully, his predictions have not been fulfilled and a little change has been taking place recently. The publication of Wolves and the Wolf Myth in American Literature by S.K. Robisch opens a new avenue in ecocritical terms towards acknowledging the agency of this non-human species in literary and cultural studies, in environmental humanities at large, while it encourages adopting Plumwoods' interspecies dialogical ethics, taking into account global interests and avoiding legends of sacrifice while giving value to the wild nature of the wolf species, reclaiming its own place in the natural world.

If we start by analyzing the book cover and the title, we already find that The Crossing is full of symbolism as it is Women who run with the wolves, the study of traditional tales and legends to empower women and facilitate a return of their wild side, which has been taken away in an era which was subordinating them under the figures of wives and mothers, from a Jungian perspective. McCarthy's novel combines his classical apocalyptic view in all the novels of The Border Trilogy (All the Pretty Horses, The Crossing and Cities of the Plain) with the idea of transcending boundaries, crossing borders and communication between different species, highlighting in any case, as Flys Junquera states, the absurdity of establishing political frontiers to separate countries whose landscape is inextricably joined (7). In this sense, the crossing in the title may also imply the conscious intention of establishing a successful interspecies dialogue, of an attempt to start cross cultural communication which is the interpretation that I will try to sustain along this study: the

* The research for this article has been done thanks to Acis\&Galatea: Project on mythcriticism (REF S2015/HUM-3362). 
crossing of boundaries between animal species or crossbreeding, the restoration of a link between the human world with the non-human animal world that has been broken through history and especially in the US where there has been a tendency in literature to demonize wolves that, as I will try to show in the following pages, McCarthy succeeds in breaking completely. McCarthy, by going back in time in his narrative, placing the reader in a past already gone and almost forgotten, brings us the need to establish relationships with communities of free living creatures, something almost lost in the time McCarthy sets the story as Plumwood argues in her discourse on interspecies ethics: "We do not know what non humans experience because we don't want to know, since doing so would oblige us to challenge accepted and profitable practices that inflict immense deprivation on commodified animals" (192).

The ethics of interspecies justice are put on the table as examples of current cruelty against packs of wolves that fight for nourishment and survival abound. They are attacked in an attempt to eliminate the menace they imply for the farmers' cattle. The attempt to make disappear and to tame the species gets portrayed clearly in Billy Parham's voyage to cross the border where as a traditional hero in search of a quest, with the fixed purpose of protecting his travel companion from hunters and trappers, he fights against this hostile environment, against the human species to claim for justice, for a space of survival to be entitled to the wolf and to himself. Following Terry Gifford's study on the pastoral genre, McCarthy in The Crossing would be using the conception of the celebration of the rural life as opposed to a urban concept (2) and thus, Flys Junquera (2010) explores in her article, related to McCarthy's possible lack of environmental consciousness, the ways of conceiving the pastoral in Leo Marx and Lawrence Buell, sustaining that nature and technology run hand in hand within the American landscape at the time the novel is published. According to the first, the pastoral in America finds desirable the middle landscape between the wilderness and the transformation of nature into a garden or farming land, the debate between the primitive and the human made landscape and he sustains his claim with examples from the literature of the time. The creation of the pastoral in America discusses Marx, owes much to Addison who in his texts

is building a theoretical bridge between the ideal of the old pastoral, the imaginary landscape of reconciliation, and a new attitude toward the environment more congenial to a scientific and commercial age. Indeed 'the mixture of garden and forest' with its 'artificial rudeness' points toward the pastoral image in America (93).

Marx defends that in the American literature of the eighteenth century:

the great revolution in science and technology we associate with Sir Issac Newton was followed by a massive shift in prevailing ideas about man's relations to nature. An effort was made to rescue the pastoral -the formal literary mode- from the confines of a decadent convention, but it failed (74-75).

Within this debate about the pastoral, communication with nature and non-human others acquires outmost importance. Thus, this idea of Billy Parham 
establishing a successful interspecies dialogue with the wolf finds reinforcement in the fact that McCarthy portrays him as unable to communicate with other human beings, except for Arnulfo. He obeys his father and tries to put up with his brother's desires but outside Las Charcas, on his pilgrimage to Mexico or in his later trips he doesn't establish any friendly connection with other humans. Braidotti argues that "post-anthropocentrism displaces the notion of species hierarchy and of a single, common standard for 'Man' as the measure of all things" (67) challenging the thesis that language can be considered "the anthropological tool par excellence" (67). Billy's response in front of the wolf can be defined as purely post-anthropocentric since he desperately attempts to make himself understood by her and as early as in page 62 , he tells that he is not going to kill her. The evolution of Billy's thought and behavior towards the animal follows the pattern that Braidotti and Plumwood describe, starting by applying human laws to the interaction because as Plumwood also argues, interspecies communication, when it does take place, is always on human terms, "the non-human species is required to learn a human language but not vice-versa" (189). In this contact between humans and animals it is always the case that other species are portrayed as inferior to humans because of their supposed lack of articulated language and the absolute necessity to objectify them in order to maintain the superiority of the human species. The process of learning that Billy undergoes, takes him to a post anthropocentric attitude asserting the elimination of a hierarchy between the child and the wolf. Thus, although Billy starts communicating with the wolf in human terms and seems to contemplate her, trying to guess how she feels every time as if she were a human being, however, he finally succeeds in establishing effective emotional communication with her and not in human terms. "A hegemonic narrative that structures the world as a human monologue will leave us little chance to perceive the other as another narrative subject, potential communicative power and agent" (Plumwood 177). They transcend the basis of human dialogue and McCarthy shows interaction between them; although Billy appears to take decisions on what it is better for the wolf on his own, he nevertheless tries to understand the needs of the animal by observation of her behavior:

Then, he reached down and felt her belly. He struggled and her eye rolled wildly. He spoke to her softly. He put the flat of his hand between her warm and naked teats. He held it there a long time. Then, he felt something move (57).

In fact, Mc Carthy repeats the idea of the wolf's watch on Billy in several pages: "The wolf sat on her haunches between him and watched him with her intractable eyes so red in the firelight" (57). They learn to understand each other by using different connections; both of them share instances of intimacy, for example, when Billy dresses her wound and she lets him do it, she seems to comply with the situation, giving him her approval and acceptance of her destiny next to him. It looks as if they agree on the steps they have to take forward to reach freedom. Billy even sings to her, improving his ways of communicating with her and painstakingly trying to establish an unbreakable bond with a member of a different species, a bond like he had never experienced before with any human or any other more 
than human being. The connection is built so fast that Billy Parham even sacrifices his life and his family to save her, as Robisch points out: "to save something wild in an increasingly hostile world" (381). McCarthy does not only portray the wolf as an icon of Nature, as the resistant force to domestication but gives agency to her "as a nonhuman conscious being" argues Robisch. Plumwood expresses that contact with animals these days is produced in a context of domestication, deprived of wilderness, "interspecies dialogue happens in a context of domesticity" from an anthropological perspective. The relationship between Billy Parham and the wolf transcends the context of domestication and focuses more on saving a life, on saving the essence of the Southwest at large. This attitude is not a product of learning and understanding as the question of communication, in fact, he was already fascinated by the animal at the beginning of the story. But it is certainly when he visits old man Arnulfo to ask for help to catch the wolf that he experiences a change: Arnulfo's visions and thoughts make an impact on Billy who returning home and reflecting on the visit feels deeply moved and already shows a concern, an interest to learn about the world of the wolf:

He lay awake a long time thinking about the wolf. He tried to see the world the wolf saw. He tried to think about it running in the mountains at night. He wondered if the wolf were so unknowable as the old man said. He wondered at the world it smelled or what it tasted. He wondered had the living blood with which it slaked its throat a different taste to the thick iron tincture of his own. Or to the blood of God (35).

As the novel advances, Billy and the wolf consolidate a relation of comradeship, until finally, at the most dramatic moment, when Billy must shoot the wolf to end her suffering, he moves from sympathy, feeling that he experiences during their entire journey until she is captured, to empathy towards her:

He talked to her a long time and as the boy tending to the wolf could not understand what it was he said he said what was in his heart. He made her promises that he swore to keep in the making. That he would take her to the mountains where she would find others of her kind. She watched him with her yellow eyes and in them there was no despair but only that that cored the world to its heart (117).

Upon feeling the wolf's blood on his thigh another example of interspecies communication takes place, they join their bloods; he realizes the blood doesn't taste different from his own (127). He even trades his rifle for her carcass in order to save her dead body from being dismembered and skinned for fur, to put her into a burial place marked with stones: "He cradled the wolf in his arms and lowered her to her ground and unfolded the sheet." (128) The ritual of burying the wolf entails a high degree of affection and even protection towards the non-human other, a true recognition of the elimination of hierarchies in their relationship.

This interpretation of McCarthy giving an agency of her own to the wolf and Billy feeling empathy for a species that it is not his own gets also sustained by the fact that Billy tries to take the wolf back to Mexico, where she belongs as she is a Canis Lupus baileyi, a Mexican wolf that Robisch states that "physically differs from a 
northern grey wolf in large part because of necessary adaptations of biology to ecology" (373), as if she were an illegal immigrant. Billy himself gets questioned and asked for his documents to cross the border. The wolf and illegal immigrants are one and the same as the song by Los Lobos "Will the Wolf survive?" proves. The song's chorus continues: In the land where he once stood with pride," reminding of the respect the wolf invoked in the past. The connection with Pinkola Estés comes with the protagonist of the video clip, a barefooted woman who crosses the border, a supposedly illegal immigrant regaining the wild aspects of femalehood. Robisch explains further that a "wolf run" is a corridor of migration or frequent travel, reinforcing once more the metaphorical meaning of The Crossing as homage to illegal immigrants: "crossing is also of metaphoric value when considering human political borders, wolf runs and pack territories or mountain passes" (374). A child and an animal represent two vulnerable creatures that McCarthy uses to draw attention to the brutality of immigration policies on the US, recently even separating children from adults in different detention centers. When crossing refers to hybridization, the crossing of species, this also connects fully with Clarissa Pinkola Estes who claims the wild status of women as a mixture of the physical human characteristics with the wild nature of the wolf. Taking the discussion of crossing borders further, The Crossing expands its meaning to a voyage between life and death, not only for the she-wolf but also for Billy himself. This voyage reminds of Dante's descent into Hell, through which Merchant affirms Dante finds dark woods filled with wild nature and beasts, one of them, paradoxically, a she-wolf.

The memento mori of the cover may stand for the cattle being killed by wolves but also for the extermination of this species from times immemorial. According to Plumwood, "an unnecessary valuation order of sacrifice" has been established by anthropocentrism among non-human species: this is a principle based on utility or usefulness. The more useful a species is for human survival, the more protected they must be against predators. On the contrary, those species which do not seem to offer immediate profit to the human race or even seem a danger or a peril for other species must be sacrificed for the common good, of course of humans. Utilitarianism has a deep anthropological basis, placing the economic interests of human beings in front of animal rights and, thus, sacrificing species whose actions may infer in elevating profits. This is how "crossing" becomes definitely associated with crucifixion and sacrifice and, along the story of Billy Parham and the wolf, the impossibility of reproduction for wolves in the South West of the US becomes evident. The female wolf is buried with her unborn pups while McCarthy warns the human race of the implications the extermination of wolves may have for the environment, of the consequences of breaking the Nature's principle of intentionality: nature intends these animals to be there. The predator must help balance the amount of other species, since also many animals of venery have been introduced for hunting purposes. Aldo Leopold insisted that "Wild life administrators are too busy producing something to shoot at to worry much about the cultural value of the shooting. Because everybody from Xenophon to Teddy Rooselvelt said sport has value, it is assumed that this value must be indestructible" (216).

He regrets there is no hope, no future either for the human race in the area because of the hierarchical structures imposed on the other living beings. 
Everybody assumes that Billy is taking the wolf in order to kill her, thus, helping farmers and humans in general to get rid of the threat her reproduction may imply. This is confirmed by the fact that his neighbors even express relief at this action when they discover that she is pregnant. It is absolutely necessary to sacrifice her in order to protect more valuable animals. In this sense, I disagree with Flys-Junquera who argues that all the non-human animals introduced by McCarthy submit to human beings in the narrative. Most adult humans in the narrative show authority and superiority but Billy, as a young adult, refuses to follow the education that has been imposed on him when he finds the wolf. Being aware of the obstacles he still must save towards adulthood, he experiences a sort of epiphany that reveals to him the destiny the wolf will run if he lets her go: be sacrificed and skinned for fur. Besides, Billy attempts to prevent the already announced extinction of the species, protecting the pups, since the wolf is pregnant. This is the reason why he answers his brother when Boyd questions his plans: "You plan on leadin that thing behind a horse?/Yessir./How you expect to get her to do that?/She aint got a whole lot of choice either. She aint got a whole lot of choice either" (45) Thus, contrary to what Flys Junquera sustains, Billy consciously protects the wolf and his progeny from trappers, from hunters, by keeping her next to him, tied, so that she doesn't run free and less sympathetic men can kill her. In fact, he starts a true crusade against the desert and its inhabitants to prevent the inevitable: the death of the wolf. If we reflect further on the fact of the gender of the wolf we can affirm with Clarisa Pinkola Estés that the wolf must die because not only anthropocentrism applies the principle of utilitarianism but specifically androcentrism searches for "the destruction of the fertile feminine," "Whether the contamination of the wild beauty takes place in the inner world or in the outer world, it is painful to witness. In modern culture, we sometimes count one as far more devastating as the other, but both are equally critical" (328). Billy's defense of the wolf in The Crossing runs parallel to the defense of the feminine wild that Clarisa P. Estés does in Women who run with the wolves: the and rocentric model of reason and moral gives humans the allowance needed to exterminate the animals as the males have been given permission to kill the creativity of women. The wolf has been given female characteristics on purpose, her gender is not casual, she seems to symbolize the extermination of the race; by killing her pups human beings are trying to get rid of an animal that causes trouble that impedes the agricultural development of the area. She is completely alone in the world; she cannot find companions to make a pack because they have all been killed. The mythological voyage to Mexico, the impossible quest for freedom, apparently to its original place, embodies the desire of Americans to expel elements alien to the culture they have created in which they have transformed and even domesticated nature for their own benefit, or at least tried tiredlessly. They still attempt to get rid of the wild, or to keep it in enclosed and protected spaces, in order to exert control over the wild elements of human culture and environment of whom the wolf is one of the most dangerous.

Manuel Broncano (2015) also develops the idea of martyrdom in his analysis from a religious point of view of McCarthy's novels and sustains, contrary to Flys Junquera's thesis, the existence of an environmental awareness/consciousness at least 
if not conscience in McCarthy, especially and specifically in this novel. Many interpretations about the Christ like figure represented in the wolf have recently appeared and about her pilgrimage to Golgotha as well, how she is taken on the road to death by means of suffering. The wolf is seized and tied to a cart to be taken to the fair. There are kids spitting on her and she is exhibited at the fair for ten cents with a sign stating up the number of people she supposedly had eaten before being captured. The dogs that fight against the wolf have been taught to communicate as humans, as aggressive humans losing touch with other types of communication within species that would have made them understand each other and enjoy each other instead of trying to kill, to exterminate the wolf: the animal they have in front of them for whom they do not experience any kind of sympathy. McCarthy thus offers a clear example of the selection of species, of the ranking that Plumwood discusses that is based on certain properties that an animal must show in order to belong to the "winning" species: to validate the use of non-humans in humans' life in terms of a hierarchy "which entitles 'more rational' humans to dominate and sacrifice nonhumans whose lives are supposedly cheaper. The dog will always qualify towards the wolf because it obeys the human, it submits to the human even if it has to fight other nonhumans while the wolf represents the embodiment of wildness and a danger to civilization, to the structures of animal domestication that the human beings have been developing from the Neolithic. The wild characteristics of the wolf have also been used in literature to inflict fear or danger into the population in romantic or Victorian novels. This idea of danger reached its peak in the context of the US during the second half of the $19^{\text {th }}$ century. What happened during this time was that the extermination of buffalos/bison whose carcasses were left to rot led to the extermination of wolves. Wolves went to be fed on those carcasses, looking for nourishment and were shot and killed at the spot as Emels states in "Are you man enough, big and bad enough? Ecofeminism and wolf eradication in the USA." (1995) She claims that strychnine was oftentimes used on the carcasses to kill wolves with the result that many other animals or Indians who came in contact with the chemical also lost their lives to the venom. While the Native Americans were being pushed onto reservations, most of the wolfers were working for commercial cattlemen, and from 1875 to 1895 the slaughter of wolves on the Plains reached its peak. Supporting the idea expressed by Plumwood in her rejection of the ranking of species, Emel states that she has found narrow symbolism, clear similarities between the extinction of the wolf and that of the Native American: "Like the Native American, the wolf was killed to secure land and investment. No less important, it was killed to sustain big game animals so that human hunters could kill them. It was killed for pelts, for data, for science, and for trophies. It was tortured, set on fire, annihilated" (720). There were attempts to reintroduce the wolf in 1995.

In The Crossing, most humans defend the extermination of wolves while Old man Arnulfo, one of a kind, expresses his respect for the wolf as a species, as a relevant part of nature and of the West. He explains to Billy that the wolf is a predator and a free spirit: 
Finally the old man repeated his words. El lobo es una cosa incognoscible, he said. Lo que se tiene en la trampa no es mas que dientes y forro. El lobo propio no se puede conocer. Lobo o to que sabe el lobo. Tan como preguntar to que saben las piedras. Los arboles. El mundo. His breath had gone wheezy from his exertions. He coughed quietly and lay still. After a while he spoke again. Es cazador, el lobo, he said. Cazador. Me entiendes? The boy didnt know if he understood or not. The old man went on to say that the hunter was a different thing than men supposed. He said that men believe the blood of the slain to be of no consequence but that the wolf knows better. He said that the wolf is a being of great order and that it knows what men do not: that there is no order in the world save that which death has put there. Finally he said that if men drink the blood of God yet they do not understand the seriousness of what they do (35).

McCarthy as Edwin Arnold demonstrates situates The Crossing in the 1930s, right before (Quoted by Emel 710) Young and Goldman classified the different types of wolves in America (Canada, USA and Mexico, mainly) in 1944. They stated that most of the animals remaining at that time were kept in national parks. According to Emel, these authors, in the employ of the US Biological Survey, noted the presence of wolves throughout most of northern Mexico. We find examples of Emel's statements in The Crossing: we find Mr Echols who took pride in chasing and hunting the wolves that crossed the border. And considerable prestige was also associated with taking the last' wolf. "Echols said there wasn't none of em did anymore" (12). "El señor Sanders me dice que el señor Echols es medio lobo el mismo. Me dice que él conoce to que sabe el lobo antes de que to sepa el lobo. But the old man said that no man knew what the wolf knew" (35).

Consequently, in ecofeminist terms and without falling in an essentialist thought of equating female humans with nature, the female characteristics of the wolf and her full womb challenge the masculine orientation of American culture and the spirit of conquest these hunters were exhibiting at the same time that they defy the conception involved in the ethics of care.

Billy Parham's pilgrimage doesn't conclude with the wolf's burial. On the contrary, he returns home to find his parents killed and his horses stolen. After recovering his horses, he loses his brother Boyd as he had done before with the wolf (trying to take her back home). Finally, he unburies his brother's bones and brings them home where he will return without having learnt the lesson. Terry Gifford laments that "Billy Parham's failure to learn from his pastoral journeys of retreat condemns him ultimately to cry the tears of loss" (3). He is condemned to wander first with animal bones and then with human ones.

McCarthy expresses his despair with the human race once more in The Crossing: there is no hope for a world in which human minds are set on killing and exterminating other animal and plant species. Unfortunately, the awakening of Billy's consciousness towards the problem of exterminating the wolf and thus destroying wild life dies with the wolf herself. During the rest of the novel, he maintains an anthropocentric attitude, using and abusing other species for his own benefit. McCarthy envisions already a future when human beings will end up with wild life as we know it and eventually exterminate each other, their own species, as he seems 
to announce when Billy witnesses the explosion of the atomic bomb at the end of the narrative. Terry Gifford discusses this in The Road and wonders whether there is hope for the future or the novel represents the expression of despair itself. This is a promise that he would soon fulfill in The Road.

Reviews sent to author: 2 June 2018 Revised paper accepted for publication: 28 July 2018 


\section{WORKS CITED}

Braidotti, R.: The Posthuman. Cambridge: Polity Press, 2013.

Broncano Rodríguez, Manuel: Religion in Cormac McCarthy's Fiction: Apocryphal Borderland. New York: Routledge, 2015.

Buell, Lawrence: The Future of Environmental Criticism: Environmental Crisis and Literary Imagination. Malden (MA): Blackwell Publishing, 2005.

EMEL, Jody: "Are you man enough, big and bad enough? Ecofeminism and wolf eradication in the USA" Environment and Planning D: Society and Space, 13 (1995): 707-734.

Flys Junquera, Carmen: "Cormac McCarthy, y la dudosa conciencia ecológica de En la frontera." La Página 87 (2010): 101-122.

Gifford, Terry: "Cormac McCarthy's The Road and a Post-Pastoral Theory of Fiction" http://www. terrygifford.co.uk/The\%20Road.pdf (retrieved July 20 ${ }^{\text {th }}$ 2017).

McCarthy, Cormac: The Crossing. New York: Vintage International, 1994.

McCarthy, Cormac: The Road. New York: Random House, 2007.

Merchant, C.: Reinventing Eden: The Fate of Nature in Western Culture. New York: Routledge, 2004.

Marx, Leo: The Machine in the Garden: Technology and the Pastoral Idea in America. Oxford: Oxford University Press, 1964.

Pinkola Estés, Clarissa: Women Who Run with the Wolves: Myths and Stories of the Wild Woman Archetype. New York: Ballantine Books, 1995.

Plumwood, Val: Environmental Culture: The Ecological Crisis of Reason. London \&New York: Routledge, 2002.

Roвish, S.K.: Wolves and the Wolf Myth in American Literature. Reno \& Las Vegas: University of Nevada Press, 2009. 
